\title{
Constrained Cyclic Peptides as Immunomodulatory Inhibitors of the CD2:CD58 Protein-Protein Interaction
}

\author{
Rushikesh Sable ${ }^{\dagger}$, Thomas Durek ${ }^{\ddagger}$, Veena Taneja ${ }^{\S}$, David J. Craik ${ }^{\ddagger}$, Sandeep Pallerla ${ }^{\dagger}$, Ted \\ Gauthier", and Seetharama Jois ${ }^{\dagger,}$, \\ †Basic Pharmaceutical Sciences, School of Pharmacy, University of Louisiana at Monroe, \\ Monroe, Louisiana 71201, United States \\ ‡The University of Queensland, Institute for Molecular Bioscience, Brisbane, Queensland 4072, \\ Australia \\ §Department of Immunology, Mayo Clinic, Rochester, Minnesota 55905, United States \\ "LSU-Ag Center, Louisiana State University, Baton Rouge, Louisiana 70803, United States
}

\begin{abstract}
The interaction between the cell-cell adhesion proteins CD2 and CD58 plays a crucial role in lymphocyte recruitment to inflammatory sites, and inhibitors of this interaction have potential as immunomodulatory drugs in autoimmune diseases. Peptides from the CD2 adhesion domain were designed to inhibit CD2:CD58 interactions. To improve the stability of the peptides, $\beta$-sheet epitopes from the $\mathrm{CD} 2$ region implicated in CD58 recognition were grafted into the cyclic peptide frameworks of sunflower trypsin inhibitor and rhesus theta defensin. The designed multicyclic peptides were evaluated for their ability to modulate cell-cell interactions in three different cell adhesion assays, with one candidate, SFTI-a, showing potent activity in the nanomolar range $\left(\mathrm{IC}_{50}: 51 \mathrm{nM}\right)$. This peptide also suppresses the immune responses in $\mathrm{T}$ cells obtained from mice that exhibit the autoimmune disease rheumatoid arthritis. SFTI-a was resistant to thermal denaturation, as judged by circular dichroism spectroscopy and mass spectrometry, and had a halflife of $\sim 24 \mathrm{~h}$ in human serum. Binding of this peptide to CD58 was predicted by molecular docking studies and experimentally confirmed by surface plasmon resonance experiments. Our results suggest that cyclic peptides from natural sources are promising scaffolds for modulating protein-protein interactions that are typically difficult to target with small-molecule compounds.
\end{abstract}

\section{Graphical abstract}

\footnotetext{
*Corresponding Author. Tel.: 318-342-1993. Fax: 318-342-1737. jois@ulm.edu. ASSOCIATED CONTENT

Supporting Information

The Supporting Information is available free of charge on the ACS Publications website at DOI: 10.1021/acschembio. $6 \mathrm{~b} 00486$.

HPLC and mass and NMR spectra of compounds, dose- response curves, CD58 expression on HFLS-RA cells using microscopy (PDF)

The authors declare no competing financial interest.
} 


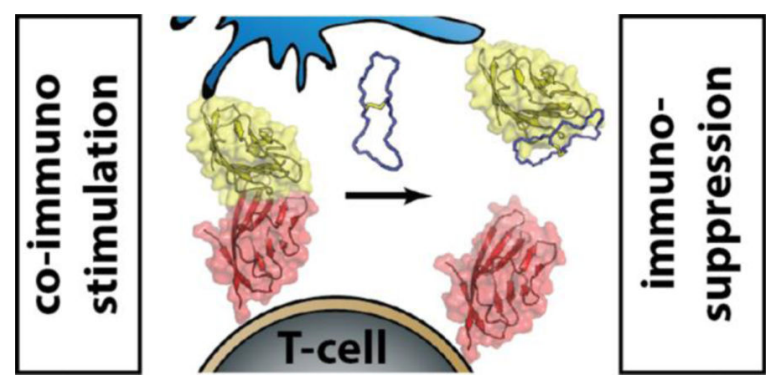

Transient cell-cell interactions and communications play a key role in the immune system and are mediated by specific complementary sets of cell surface proteins. One such interaction is the protein-protein interaction between the integral membrane glycoproteins CD2 and CD58 (also called leukocyte function associated antigen-3, LFA-3), which modulates cell adhesion between T cells (CD2) and epithelial cells (CD58/CD48 in rodents). ${ }^{1,2} \mathrm{CD} 2$ is expressed on both $\mathrm{CD} 4+$ and $\mathrm{CD} 8+\mathrm{T}$ cells and is up-regulated upon Tcell activation, whereas CD58 is overexpressed by antigen-presenting cells in autoimmune diseases. ${ }^{3,4}$ The interaction between CD2 and CD58 has significant importance in autoimmune diseases such as rheumatoid arthritis (RA). ${ }^{5-7}$ The results of large genomewide association studies (GWAS) suggest that more than 30 loci are involved in RA pathogenesis, and CD2 as well as CD58 is important. ${ }^{6}$ Previous reports have indicated that inhibition of the CD2 and CD58 interactions using a LFA-3 fusion protein (alefacept) inhibits T-cell activation. ${ }^{8} \mathrm{CD} 2$ can be effectively targeted by peptides derived from CD58 as well as fusion protein constructs. ${ }^{9}$ However, direct targeting of CD2 on T cells might interfere with other signaling mechanisms, and in the case of RA, synovial epithelial cells overexpress CD58. Thus, we reasoned that targeting upregulated CD58 (instead of CD2) may be a more effective strategy.

The CD58-binding interface of CD2 comprises a flat $\beta$-sheet with multiple charged residues, which engages face-to-face with another $\beta$-sheet from CD58 as shown in Figure $1 .{ }^{10}$ In our earlier work, we used the strategy of designing epitopes from cell surface proteins and conformationally constrained them using cyclization and turn-inducing Pro-Pro motifs. ${ }^{11}$ We demonstrated that cyclic peptides derived from CD2 could be used to block cell adhesion between T cells and Caco-2 cells expressing CD2 and CD58, respectively. ${ }^{11,12}$ The best candidate, peptide 6 (Table 1), was able to suppress the progression of disease in a collageninduced arthritis (CIA) model. ${ }^{13}$ Although the designed peptides had in vitro and in vivo activity, like most other peptides they have limitations in their in vivo stability. ${ }^{14}$ Our new strategy was to use the biologically active peptide epitope we designed and improve its stability. To enable this strategy, we made use of naturally occurring head-to-tail cyclic peptides that are highly resistant to enzymatic, chemical or thermal, degradation and have been previously explored for pharmaceutical applications. ${ }^{15}$ These peptides are amenable to sequence engineering, including the grafting of foreign epitopes into their sequences, and because of their remarkable stability are generally considered to have low immunogenicity. ${ }^{15}$ Most of these naturally occurring cyclic peptides contain structurestabilizing disulfide bridges, which together with $\mathrm{N}$-to-C cyclization results in exceptionally rigid and well-defined 3D structures. Examples of these "miniproteins" include the plant- 
derived cyclotides ( $30 \mathrm{AA}$, three disulfide bridges),${ }^{16}$ sunflower trypsin inhibitor (SFTI, $14 \mathrm{AA}$, one disulfide bond), ${ }^{17}$ and the mammalian rhesus theta defensins (RTD, $20 \mathrm{AA}$, three disulfides). ${ }^{18,19}$

Structural comparison of various naturally occurring cyclopeptides suggested that the sunflower trypsin inhibitor and theta defensin frameworks could be ideal starting points for grafting of CD2 epitopes. Structurally, both frameworks are composed of antiparallel $\beta$ strands, which are stabilized by one (SFTI) ${ }^{17}$ or three disulfide bridges (RTD).${ }^{19}$ Here, we grafted the CD2 adhesion domain sequence from peptide 6 onto the SFTI and RTD frameworks and studied their ability to modulate cell-cell adhesion in cellular assays. Among the grafted peptides, SFTI-a exhibited significant cell adhesion inhibitory activity in three different cellular assays. Furthermore, we evaluated the ability of these peptides to inhibit T-cell immune responses in cells obtained from a transgenic mouse model relevant to the autoimmune disease RA. The designed cyclic peptide showed improved resistance toward thermal and enzymatic degradation.

\section{RESULTS AND DISCUSSION}

\section{Design and Synthesis of Grafted Peptides}

Our approach was to graft a cyclic peptide framework with sequences from the CD2 adhesion domain. This domain contains the $\mathrm{F}$ and $\mathrm{C} \beta$-strands that form the main $\mathrm{CD} 2$ interface interacting with $\mathrm{CD} 58 .{ }^{10} \mathrm{In}$ an earlier publication, we described the design of peptide 6 , which exhibits a $\beta$-strand/ $\beta$-hairpin structure that is stabilized by a $\beta$-turninducing D-Pro-L-Pro motif. ${ }^{11}$ We used the topology of peptide 6 as well as the $\mathrm{F}$ and C strands of CD2 from the crystal structure of CD2 ${ }^{10,20}$ to design grafted analogs of SFTI and RTD (Figure 1). The disulfide-stabilized, antiparallel $\beta$-strand conformation of these molecules (PDB ID: 1JBL, 4TTK, 2LYF, 2ATG) ${ }^{19,21-23}$ was utilized as a template to introduce several mutations (Figure 1) to generate mimics of the CD2 F/C strand region. Our design strategy focused on one face of the $\beta$-strand. In a $\beta$-strand, the side-chains of every second residue are on the same face of the sheet; thus, we introduced mutations mainly in alternating positions. For example, in RTD- 1 , in which the core of the antiparallel $\beta$-sheet is formed by two CXCXC motifs, the three disulfides localize on one side of the flat $\beta$-sheet and the Xaa side-chains on the other. Similar conformations are seen in the structure of SFTI-1. By keeping the disulfide pattern and bonding intact and minimizing changes within the turn regions, we expected minimal overall structural perturbations. Importantly, both frameworks are slightly larger than peptide 6 , which facilitated grafting of more complex and extended CD2 epitopes, which we aimed to translate into greater affinity of the resulting grafted analogs for CD58. The design process was aided by the YASARA modeling suite. ${ }^{24}$ Two SFTI-1 analogs (SFTI-a and SFTI-b) and three RTD-1 analogs (RTD-a, RTDb, and RTD-c) were selected for pharmacological evaluation, synthesized by Fmoc solid-phase peptide synthesis, cyclized, and folded using a recently described procedure. ${ }^{25}$

\section{Cell Adhesion Inhibition Assay}

The ability of peptides to inhibit the $\mathrm{CD} 2$ :CD58 protein-protein interaction was studied by evaluating the adhesion interaction between cells using model systems. T cells express the 
CD2 protein, and CD58 is expressed in many epithelial cells as well as antigen-presenting cells. Many studies related to CD2 expression and CD2 signaling use Jurkat cells. ${ }^{26-28}$ These cell lines serve as good models and have stable expression of CD2. Furthermore, in many drug discovery and mechanistic screening studies, model cell lines that express particular proteins are used. The model systems we used included Jurkat and ovarian cancer cells -3 (OVACR-3) cells, Jurkat and sheep red blood cells (SRBC), and Jurkat and human fibroblast-like synoviocyte-rheumatoid arthritis (HFLS-RA) cells. Since OVCAR-3 cells, SRBCs, and HFLS-RA cells express CD58, adhesion interactions between CD2 and CD58 can be studied using these model systems. Peptides were incubated with adherent cells that expressed CD58, and Jurkat cells were added to evaluate the adhesion. Inhibition of adhesion was monitored by fluorescence of Jurkat cells loaded with $2^{\prime}, 7^{\prime}$-bis(2carboxyethyl)-5-(and-6)-carboxyfluorescein acetoxymethyl ester (BCECF AM). A broad range of concentrations ( 0.0005 to $200 \mu \mathrm{M}$ ) was used in the first screen, and based on the inhibitory activity of the peptides in that concentration range, data points for a doseresponse study were chosen. The concentration-response curves for the various peptides were obtained in the range of 0.0005 to $10 \mu \mathrm{M}$. Among the peptides studied, SFTI-a and RTD-c exhibited significant cell adhesion inhibitory activity (Table 1). In the lymphocyte epithelial cell assay using Jurkat and OVCAR-3 cells (Figure 2), the $\mathrm{IC}_{50}$ value for cell adhesion inhibition for SFTI-a was $43 \pm 25 \mathrm{nM}$, and RTD-c exhibited an $\mathrm{IC}_{50}$ value of 27 $\pm 15 \mathrm{nM}$ (Figure 2A,B). Other cyclic peptides such as SFTIb, RTD-a, and RTD-b showed weak inhibitory activity, with $\mathrm{IC}_{50}$ values higher than $50 \mu \mathrm{M}$. A negative-control peptide, which was derived from the CD2 adhesion domain but with an inverse sequence, had inhibitory activity only above $100 \mu \mathrm{M}$.

Cell adhesion was also evaluated in a well-established E-rosetting assay, ${ }^{29,30}$ and SFTI-a inhibited adhesion with an $\mathrm{IC}_{50}$ of $51 \pm 10 \mathrm{nM}$ in this assay (Figure 2C). To evaluate the cell adhesion inhibitory activity of peptides from cells associated with autoimmune disease, we used HFLS-RA cells derived from RA patients. The expression of CD58 on HFLS-RA cells was evaluated using flow cytometry and fluorescence microscopy (SI Figure 8). After establishing CD58 expression on HFLS-RA cells, the cell adhesion assay was carried out. SFTI-a inhibited cell adhesion between Jurkat cells and HFLS-RA cells with an $\mathrm{IC}_{50}$ of 51 $\pm 25 \mathrm{nM}$ (Figure 2D). The unmodified scaffold, SFTI-1, exhibited cell adhesion inhibitory activity of less than $20 \%$ only at a relatively high concentration $(5 \mu \mathrm{M})$.

Comparison of the CD2 F and C strands and the modeled structures of the designed SFTI and RTD analogs suggested that placement of Asp, Tyr, Ser, and Lys amino acids (corresponding to D87, D31, Y86, D32, S84, and K34 in CD2; with the single letter code used for amino acids from $\mathrm{CD} 2$ protein and the three letter code used for amino acids from peptides) is critical for high affinity binding to CD58. ${ }^{20}$ In SFTI-a and RTD-c, these amino acid residues are displayed in an orientation where they can be presented to the receptor CD58. The Val and Ile residues that correspond to V83, I85, and I33 in CD2 do not seem to play a role in binding to CD58, as indicated by the inactive peptide RTD-a. On the other hand, Lys and Glu residues that correspond to K82 and E36 in the F and C strands appear to play a minor role in binding (RTD-c). In peptide 6 , the $\mathrm{IC}_{50}$ for cell adhesion inhibition is $6.9 \mathrm{nM}$. When the amino acids in peptide 6 were incorporated into the SFTI-1 or RTD-1 framework, the activity was reduced slightly, as can be seen from the $\mathrm{IC}_{50}$ s of SFTI-a and 
RTD-c (43 and $27 \mathrm{nM}$, respectively, in OVCAR-3-Jurkat assy). However, SFTI-b and RTD-a and RTD-b exhibited cell adhesion inhibition activity at very high concentrations ( $>50 \mu \mathrm{M})$. The loss in the cell adhesion inhibition activity in these peptides compared to SFTI-a is presumably because of the differing placement of key amino acids in the SFTI framework. These results suggest that amino acids from the CD2 structure that are important in binding to CD58 and their position in the cyclic framework are important in the design. Overall, the data confirm that SFTI-a and RTD-c are potent inhibitors of cell adhesion.

\section{Cell Viability Studies}

We presumed that SFTI-a and RTD-c exhibit their cell adhesion inhibitory activity by inhibiting the protein-protein interaction between CD2 and CD58. The observed inhibition of adhesion, due to peptide binding and not cytotoxicity, was verified by the evaluation of cell viability of the peptides in OVCAR-3 and HFLS-RA cells. The studies suggested that SFTI-a and RTD-c were not toxic to cells at concentrations up to $100 \mu \mathrm{M}$. At $200 \mu \mathrm{M}$, cell viability was nearly $65 \%$, suggesting that these peptides are cytotoxic only at relatively high concentrations (SI Figure S9).

\section{Antibody Binding Inhibition}

Peptides were designed from the adhesion domain of CD2; hence, we assumed that the designed peptides bound to CD58 in a similar manner to CD2 and inhibited the CD2:CD58 protein-protein interaction. To demonstrate that this was the case, an antibody-binding inhibition assay (competitive binding assay with antibody) was used with flow cytometry detection. An anti-CD58 FITC-antibody, which binds to CD58 covering the CD2 binding site, ${ }^{31}$ was incubated with HFLS-RA cells for $15 \mathrm{~min}$, followed by the addition of increasing concentrations of SFTI-a $(10,50$, and $100 \mu \mathrm{M})$. After $1 \mathrm{~h}$ of incubation, binding of FITCantiCD58 was monitored by flow cytometry. Untreated cells (without antibody and peptide) were used as controls. FITC-CD58-antibody-bound HFLS-RA cells showed a shift in the population of cells to the right compared to cells without FITC-CD58Ab (Figure 3A). In the presence of SFTI-a $(100 \mu \mathrm{M})$, a leftward-shift in the population of cells compared to antibody-bound cells was observed, suggesting that SFTI-a effectively competes with the antibody for binding to CD58.

\section{Binding of SFTI-a to CD58 Protein Analyzed by Surface Plasmon Resonance (SPR)}

The results of the competitive antibody-binding assay suggested that SFTI-a binds to CD58 on cell surfaces. To further demonstrate SFTI-a binding to the purified cell-adhesion domain of CD58 in vitro, we carried out binding studies using SPR with immobilized CD58. ${ }^{32}$ The analysis suggested that SFTI-a binds to the CD58 protein in a concentration-dependent manner (Figure 3B). As a control, soluble CD2 and anti-CD58 antibody were used. Since these proteins have high molecular mass, the binding-response amplitude was significantly higher compared to the small peptide SFTI-a (SI Figure S10). The results of the SPR studies clearly suggest that SFTI-a binds in a concentration-dependent manner to domain 1 of CD58, which contains the adhesion domain. Kinetic parameters were obtained by fitting data to the $1: 1$ binding Langmuir equation. For SFTI-a, the $k_{\text {on }}$ was $224.4 \mathrm{M}^{-1} \mathrm{~s}^{-1}$ and the $k_{\text {off }}, 0.00329 \mathrm{~s}^{-1}$; from these values, the $K_{\mathrm{d}}$ was calculated as $14.6 \mu \mathrm{M}$. In comparison, SFTI-1 had a $K_{\mathrm{d}}$ value of $>500 \mu \mathrm{M}$. The $K_{\mathrm{d}}$ for binding of SFTI-a to CD58 is in the 
micromolar range, while the inhibitory activity of SFTI-a is in the nanomolar range. However, this binding is sufficient to inhibit the CD2:CD58 interaction because this interaction is relatively weak $\left(K_{\mathrm{d}} 10 \mu \mathrm{M}\right)$, but highly specific. ${ }^{33,34}$

\section{SFTI-a Suppresses the T-Cell Response and Is Nonimmunogenic in Vivo}

The cell adhesion assay described above suggests that SFTI-a and RTD-c inhibit the cell adhesion interaction between Jurkat cell lines and epithelial cells, as well as between Jurkat cell lines and HFLS-RA cells. To evaluate the ability of peptides to suppress the immune response in a relevant animal model, HLA-DQ8.AEo transgenic mice were used. Since costimulation via $\mathrm{CD} 2$ on $\mathrm{T}$ cells is involved in the generation of an immune response via antigen presentation, we speculated that $\mathrm{CD} 2$-derived peptides should inhibit the interaction between T cells and APCs, thus suppressing the T-cell response. Immunization of HLADQ8 mice with type II collagen leads to antigen-specific cellular and humoral responses, causing animals to develop arthritis. ${ }^{35-37}$ Lymph node cells (LNCs) harvested from CIIprimed mice were cultured in the presence or absence of CII and peptides in vitro, and cell proliferation was monitored using the ${ }^{3} \mathrm{H}$-thymidine assay. Our observations indicated that SFTI-a and RTD-c concentration-dependently suppress the T-cell response to CII in vitro (Figure 4A). These results suggest that CD2-derived peptides can be used to suppress antigen-specific immune responses.

To evaluate the immunogenicity of SFTI-a and RTD-c in vivo, DQ8 mice were primed with SFTI-a and RTD-c. LNCs extracted from these mice were challenged with SFTI-a and RTD$\mathrm{c}$ in vitro, and the proliferation of T cells was evaluated. SFTI-a did not show a significant immune response at $50 \mu \mathrm{g} / \mathrm{mL}$ compared to both the control and conconavalin A, suggesting that SFTI-a is not immunogenic (Figure 4B). On the other hand, LNCs showed a significant immune response when challenged with RTD-c in vitro at $50 \mu \mathrm{g} / \mathrm{mL}$, suggesting that RTD-c is immunogenic (SI Figure S12). Although the wildtype cyclic peptides are known to be nonimmunogenic, introduction of the human sequence into these peptides, by grafting the RTD peptide, may result in a structure that is suitable for generating immunogenicity. Because of the immunogenicity of RTD-c, we carried out further stability studies on SFTI-a only.

\section{Stability Studies by CD Spectroscopy and Mass Spectrometry}

Peptides with a backbone cyclic structure stabilized by disulfide bridges typically have higher thermal stability than unconstrained macromolecules. ${ }^{18}$ To evaluate the thermal stability of SFTI-a, circular dichroism spectroscopy was utilized. The CD spectrum of SFTIa exhibited a negative band around $205 \mathrm{~nm}$ and a positive band at $190 \mathrm{~nm}$, in agreement with a turn $/ \beta$-strand conformation of the peptide at $25^{\circ} \mathrm{C}$. There was no significant change in the CD spectra of SFTI-a at different temperatures, indicating that the secondary structure of the peptide was unchanged (Figure 5A). To confirm that covalent structure remains intact during the experiment, a mass spectrum of a sample of SFTI-a was obtained from the solution used to record the $\mathrm{CD}$ spectrum and showed that the molecular ion before and after heating to $85^{\circ} \mathrm{C}$ was the same. Thus, the $\mathrm{CD}$ and mass spectrometry results confirm that SFTI-a is stable against thermal denaturation (Figure 5A-D). To further evaluate stability, the CD spectrum of SFTI-a was monitored in the presence and absence of various concentrations of 
dithiothreitol (DTT). The addition of DTT resulted in changes in the CD spectrum of SFTIa, suggesting that a reduction in the disulfide bonds changes the conformation of the peptide. Reduction was confirmed by a shift in the molecular ion of SFTI-a upon the addition of DTT $(\mathrm{m} / z 1408$ to 1410 upon addition of DTT, SI Figures S15 and S16).

\section{Serum Stability}

To evaluate the stability of SFTI-a toward enzymatic degradation ${ }^{38-40}$ under physiologically relevant conditions, the peptide was incubated in human serum, and the amount of intact peptide remaining was determined by HPLC and mass spectrometry ${ }^{41}$ over $24 \mathrm{~h}$. Both methods gave similar results, and SFTI-a was detectable in human serum at all time points (0-24 h). Due to its remarkable stability, the precise half-life of the compound could not be calculated from the degradation profile; however, the data suggest that the half-life in human serum is at least $24 \mathrm{~h}$ (Figure 6). Overall, the data suggest that SFTI-a is likely to be stable in vivo.

\section{NMR and Molecular Modeling}

Detailed NMR studies were carried out on the most promising molecule, SFTI-a. Interestingly, 2D TOCSY and NOESY NMR experiments under various conditions yielded complex spectra indicative of conformational heterogeneity. SFTI-a contains two prolines and one disulfide bond, which in principle can give rise to eight possible conformational isomers (four prolyl-cis/trans isomers and two pro-R/pro-S disulfide bond isomers). The spectra provide experimental evidence for four isomers that coexist in solution in an approximate ratio of 34:30:28:8 (based on the observation of four defined TOCSY spin systems for the single Lys2 residue, SI Figure S4). The structural heterogeneity is most pronounced in the constrained $\mathrm{C}^{1} \underline{\text { KASAPPS }} \mathrm{C}^{9}$ loop, suggesting that the different conformations probably arise from Xaa-Pro cis/trans isomerization that is slow on the NMR time scale. Further evidence for this slow conformational exchange was obtained by variable temperature HPLC analysis, which suggested that the alternative conformations are interconverting slowly on the HPLC and NMR time scales (SI Figure S5). Analysis of the TOCSY and NOESY spectra indicated that in at least one of the four conformers the Ala ${ }^{5}-$ $\mathrm{Pro}^{6}$ peptide bond adopts a cis configuration (strong $\mathrm{Ala}^{4} \mathrm{aH}_{-} \mathrm{Pro}^{5} \mathrm{aH}$ NOE), while the $\mathrm{Pro}^{6}-\mathrm{Pro}^{7}$ peptide bond is in the trans configuration (strong $\operatorname{Pro}^{6} \mathrm{aH}-\mathrm{Pro}^{7} \delta \mathrm{H}$ NOEs). The same configurations (i.e., cis-trans) of these two consecutive Pro residues are observed in wt SFTI-1, but in that case there is no evidence of additional conformers (SI Figure S6). In the case of SFTI-a, it is likely that the cis-cis, trans-trans, and trans-cis forms are also populated, although we cannot exclude heterogeneity (i.e., pro-R/pro-S) around the disulfide bond. The conformational heterogeneity precluded unambiguous assignment of the NMR spectra, which prompted us to analyze SFTI-a via in silico molecular dynamics (MD) simulations.

The SFTI-a structure, built using YASARA molecular modeling software, was subjected to a MD simulation in a water box at $300 \mathrm{~K}$ for $400 \mathrm{ps}$. The overall backbone structure of SFTI-a was stable during the simulation, as shown by small RMSD from the starting structure (Figure 7A). Some flexibility on the nanosecond time scale was found around the Pro-Pro sequence, as well as the Gly-Asp-Asp sequence, as shown in Figure 7A. There was no 
indication of a change in the disulfide bond conformation or the Pro-Pro configuration, but such changes would be expected to occur only over a longer time scale. The fast local flexibility in the Pro-Pro region is however entirely consistent with a susceptibility of this region to proline isomerization as suggested by the NMR data. By contrast, the SFTI-1 peptide shows less flexibility on the nanosecond time scale (Figure 7B), consistent with its reduced tendency for proline isomerization. Data from the literature suggest that peptides from the Bowman-Birk inhibitor family exhibit conserved cis bond configuration at the Xpro bond. ${ }^{42}$ Tischler et al. ${ }^{43}$ proposed strategies for locking the amide bond leading to one particular conformation by incorporating triazole based mimetics in the peptide. Such strategies could be used in the future to lock SFTI-a into one conformation.

To model the peptide-CD58 complex, docking studies were carried out using Autodock software ${ }^{44}$ From the cellular assays and SPR studies it became clear that designed peptides bind to the CD58 protein adhesion domain and inhibit the cell-cell interaction. Hence, during docking studies, a grid was created, centered on the adhesion domain of CD58, and the binding modes of SFTI-a and RTD-c were calculated. Among the 50 low energy structures generated, the 10 structures that had docking energies within $2 \mathrm{kcal} / \mathrm{mol}$ of the lowest docked energy were chosen to represent the mode of binding of SFTI-a and RTD-c to CD58 (Figure 7C and D). For final analysis, one of the low energy docked structures that was bound near the adhesion domain of CD58 was chosen as a representative structure. In the case of SFTI-a, the docked structure was bound near the amino acids that are important in binding to CD58. K34 of CD58 participated in a hydrogen bonding interaction with a Ser side chain and Pro backbone carbonyl. The side chain of D33 of CD58 formed a salt bridge with the side chain of Lys of SFTI-a. Similarly, the side chain of K32 of CD58 formed a hydrogen bond with the side chain of Asp of SFTI-a. Considering mutational studies of the CD2:CD58 interaction, the mode of binding of SFTI-a, which involves amino acids of protein $\mathrm{K} 32$, K34, and D33 may block the CD2:CD58 interaction. In the case of the RTDc:CD58 interaction, a similar mode of binding SFTI-a:CD58 was observed. The hydrogen bonding interactions observed were between K32 of CD58 with Asp of RTD-c, K29 with Tyr, K34 with Cys, R44 with Glu and Lys, and E42 with Lys. In the low energy docked structures, the orientation of peptides (SFTI-a and RTD-c) with respect to the F and C strands of CD58 was at an angle to the beta strands. This orientation was similar to that observed in the CD2:CD58 interaction, where CD2 F and C strands interact with CD58 $\beta$ strands in an orthogonal orientation in a hand shaking fashion. ${ }^{10}$

\section{Conclusions}

Peptide sequences from the cell adhesion/ costimulatory molecule CD2 were grafted into cyclic peptide frameworks. The designed peptides were evaluated for their cell adhesion inhibitory activity using model cell systems, as well as HFLS-RA cells derived from human RA. One of the peptides exhibited cell adhesion inhibitory activity in the low nanomolar range and was able to suppress T-cell activation derived from humanized arthritic mice. The peptide was nonimmunogenic and could bind to the CD58 protein in vitro. The peptide was stable against thermal degradation and in serum. Such peptides that modulate the immune response by modulating protein- protein interaction of costimulatory molecules may be utilized as therapeutic agents for autoimmune diseases like RA. 


\section{MATERIALS AND METHODS}

\section{Cell Lines/Cells}

The human ovary adenocarcinoma epithelial cell line (OVCAR-3) and the T-leukemia Jurkat cell line were purchased from the American Type Culture Collection (Rockville, MD).

OVCAR-3 cells were maintained in RPMI-1640 medium formulated by the American Type Culture Collection (Rockville, MD), with $20 \%$ FBS, $0.01 \mathrm{mg} \mathrm{mL}^{-1}$ bovine insulin, and 0.1 $\mathrm{mg} \mathrm{mL} \mathrm{m}^{-1}$ penicillin/streptomycin. Jurkat cells were also maintained in RPMI1640 medium supplemented with $10 \% \mathrm{FBS}$ and $0.1 \mathrm{mg} \mathrm{mL}^{-1}$ penicillin/streptomycin. Human rheumatoid arthritis fibroblast-like synoviocyte cells (HFLS-RA) were purchased from Cell Applications Inc. (San Diego CA). HFLS-RA cells were grown in Human Synoviocyte Media provided by Cell Applications (San Diego, CA). Sheep red blood cells (SRBC) in Alsevers solution were ordered from Colorado Serum Company (Denver, CO).

\section{Peptide Synthesis}

Cyclic peptides (Table 1) were synthesized using the Fmoc solid-phase peptide synthesis method described previously. ${ }^{25}$ The structures of peptides were studied using NMR, with details provided in the Supporting Information.

\section{Lymphocyte Cell Adhesion Assay}

Approximately $1 \times 10^{4}$ OVCAR-3 cells were coated per well in 96-well plate. After confluency was achieved, the monolayer was washed with PBS and the assay was carried out using the protocol previously established in our laboratory. ${ }^{45}$ Dimethyl sulfoxide was used to prepare stock solutions of peptides $\left(2 \mathrm{mg} \mathrm{mL}^{-1}\right)$. Different concentrations of these cyclic peptides were prepared by diluting the above stock solution in RPMI1640 media (without any additives). In the final solutions, the concentration of DMSO was less than $1 \%$. After the inhibition assay, the fluorescence of the obtained lysates was determined with a microplate fluorescence analyzer (Biotek Synergy, Winooski, VT) with excitation at $485 \mathrm{~nm}$ and emission wavelength at $528( \pm 20) \mathrm{nm}$. The data are represented as percent inhibition, by considering the fluorescence intensity obtained for cells in the monolayer without inhibitor as no inhibition or $0 \%$ inhibition. Results for all peptide concentrations were normalized to the antibody inhibition, which was considered to be $100 \%$ inhibition. ${ }^{45}$ CD58 antibody (Santacruz Biotechnology Inc. Dallas, TX) dilutions were used as positive controls for the experiments. Similar experiments were done with HFLS-RA cell lines. A negative control peptide (Table 1) was also used.

\section{Cell Viability Assay}

The potent compounds obtained from the lymphocyte cell adhesion assay were further tested for the toxicity by using CellTiter Glo Assay kit (Promega Corporation, Madison, WI).

\section{E-Rosetting Assay}

This assay was carried out as described previously. ${ }^{45}$ Different SFTI-a concentrations (100$0.01 \mu \mathrm{M})$ were prepared from the stock solution $\left(2 \mathrm{mg} \mathrm{mL}^{-1}\right)$ in PBS. Sheep red blood cells and Jurkat cells were incubated in the presence or absence of peptides. From each area on a 
slide, 200 Jurkat cells were counted, from which a percentage of E-rosettes was determined for each concentration. ${ }^{46}$ A sample without SFTI-a was used as a negative control (detailed explanation in Supporting Information).

\section{Competitive Binding Studies}

Flow cytometry was used to determine the competitive binding of SFTI-a with FITC-labeled CD58 antibody to the OVCAR-3 and HFLS-RA cells. All samples were analyzed with FL1 fluorescence and side scatter detectors for dot plots. Histograms for cell population according to fluorescence (FL1) were plotted for varying concentrations of SFTI-a. Cells only and cells with no SFTI-a were used as positive and negative controls, respectively. Similar experiments were done with HFLS-RA cells (detailed explanation in Supporting Information).

\section{Surface Plasmon Resonance (SPR) Binding Assay}

The binding efficiency of SFTI-a to CD58 protein was analyzed by SPR (Biacore X100). CD58 protein was immobilized on flow cell 2 of a CM5 SPR sensor chip (GE Healthcare Life Sciences Pittsburgh PA), in pH 4 acetate buffer, while flow cell 1 was kept as a blank for reference. Various concentrations of SFTI-a $(0.5-200 \mu \mathrm{M})$ prepared in HBS-EP buffer (GE Healthcare Life Sciences Pittsburgh PA), were passed through both flow cells with an association time of $180 \mathrm{~s}$ and a dissociation time of $200 \mathrm{~s}$, for the recording binding responses. SFTI-1, CD2 protein, and CD58 antibody were used as controls for the experiment (detailed explanation in the Supporting Information).

\section{Inhibition of T-cell Proliferation in HLA-Transgenic Mice}

Transgenic mice expressing functional HLA-DQ8 (DQA1*0301/DQB1*0302)) molecules and lacking endogenous class II molecules (DQ8.AEo) have been described previously. ${ }^{47}$ Mice used in this study were bred and maintained in the pathogen-free Immunogenetics Mouse Colony of the Mayo Clinic, and all experiments were carried out according to protocols approved by the Institutional Animal Care and Use Committee. HLA-DQ8 mice were immunized with $100 \mu \mathrm{L}$ of type II collagen (CII, $2 \mathrm{mg} \mathrm{mL}^{-1}$; Chondrex) emulsified 1:1 with complete Freund's adjuvant (CFA; Difco), by intradermal injection at the base of the tail. Ten days postimmunization, mice were sacrificed, and draining popliteal, caudal, and lumbar lymph nodes were removed and prepared for in vitro culture. LNCs $\left(1 \times 10^{6}\right)$ were suspended in HEPES-buffered RPMI 1640 containing 5\% heat-inactivated horse serum and antibiotics streptomycin and penicillin. LNCs were then challenged with $100 \mu \mathrm{L}$ of RPMI containing concanavalin A (20 $\mu \mathrm{g} / \mathrm{mL}$, positive control), native collagen $(50 \mu \mathrm{g} / \mathrm{mL})$, and medium alone (negative control). To the cells challenged in vitro with CII at $50 \mu \mathrm{g} / \mathrm{mL}$, peptides SFTI-a and RTD-c were added at concentrations ranging from 5 to $100 \mu \mathrm{g} / \mathrm{mL}$, and cells were incubated for $48 \mathrm{~h}$ at $37{ }^{\circ} \mathrm{C}$. The cells were pulsed with ${ }^{3} \mathrm{H}$-thymidine $(1 \mu \mathrm{Ci} /$ well) during the last $18 \mathrm{~h}$. At the end of the assay, the cells were harvested using a plate harvester and incorporated radioactivity was determined using an automated counter (Microbeta, PerkinElmer Wallac) for T-cell proliferation. Results are depicted as stimulation index (S.I.). 


\section{Immunogenicity Studies}

To determine the immunogenicity of SFTI-a, DQ8 mice were immunized with the $200 \mu \mathrm{L}$ of peptide at $50 \mu \mathrm{g} / \mathrm{mL}$. Mice were monitored for stress and any related phenotype. Ten days after immunization, mice were sacrificed, and draining lymph nodes were harvested and cultured in vitro as described above, in either the presence or absence of the peptide. ConA $(1 \mu \mathrm{g} / \mathrm{mL})$ was used as a positive control. During the last $18 \mathrm{~h}$, the cells were pulsed with ${ }^{3} \mathrm{H}$-thymidine $(1 \mu \mathrm{Ci} /$ well $)$. At the end of the assay, the cells were harvested using a plate harvester, and incorporated radioactivity was determined using an automated counter (Micrebeta, PerkinElmer Wallac) for T-cell proliferation.

\section{Thermal Stability}

SFTI-a was dissolved in deionized water to a concentration of $15 \mu \mathrm{M}$. The "Temperature Interval Measurement" mode of a JASCO-815 (Jasco Inc., Easton, MD) circular dichoism spectrometer was used to monitor peptide stability as a function of temperature. The ellipticity of the SFTI-a solution was measured at temperatures between 25 and $85^{\circ} \mathrm{C}$ in increments of $5{ }^{\circ} \mathrm{C}$. Mass of the SFTI-a was confirmed at $25^{\circ} \mathrm{C}, 50{ }^{\circ} \mathrm{C}$, and $85^{\circ} \mathrm{C}$ and also at the end of the experiment. To further confirm the stability of the disulfide bond, $\mathrm{CD}$ spectra of SFTI-a were recorded in the presence and absence of DTT $(0,0.1$, or $1 \mathrm{mM}$ of DTT). After the CD experiment, samples were freeze-dried and mass spectra were obtained using MALDI-TOF mass spectrometry. As a control, freshly prepared peptide sample was used.

\section{Serum Stability}

Normal human serum was purchased from Innovative Research (Novi, MI) and used, according to approved guidelines, in a biosafety II cabinet with IBC certification. SFTI-a stock solution $\left(2 \mathrm{mg} \mathrm{mL}^{-1}\right)$ prepared in PBS was used for the experiment. Stock solution was incubated in human serum (Innovative Research, Court Novi, MI) at a ratio of 1:9 at $37^{\circ} \mathrm{C}$ at various time points from $0 \mathrm{~min}$ to $24 \mathrm{~h} ; 100 \mu \mathrm{L}$ of this mixture was sampled and treated with $500 \mu \mathrm{L}$ of cold acetonitrile for SFTI-a extraction. Samples were analyzed as described previously. ${ }^{12}$ Using the sample procedure, samples were prepared for HPLC analysis. Another cyclic control peptide (compound 35) was used as an internal standard to get the relative intensity in mass spectra.

\section{Docking}

Docking studies were carried out using Autodock Tools and Autodock ${ }^{44}$ version 4.2 (details in Supporting Information).

\section{Simulations}

MD simulations of SFTI and SFTI-a in solvent were carried out by using NAMD software available in Discovery Studio (BIOVIA, San Diego CA). Final structures were displayed using PyMol software. 


\section{Supplementary Material}

Refer to Web version on PubMed Central for supplementary material.

\section{Acknowledgments}

Computational studies were carried out on a high-performance computer (HPC) at LSU, Baton Rouge via the Louisiana Optical Network Initiative (LONI). This work was partly supported by a Louisiana Biomedical Research summer research project from the National Institute of General Medical Sciences of NIH under grant number 8P20GM103424, and Louisiana Campuses Research Initiative (LaCRI) grant. We gratefully acknowledge funding from the Australian Research Council (DP150100443). DJC is an Australian Research Council Laureate Fellow (FL150100146). VT is supported by grant AR30752.

\section{REFERENCES}

1. Davis SJ, Ikemizu S, Wild MK, van der Merwe PA. CD2 and the nature of protein interactions mediating cell-cell recognition. Immunol. Rev. 1998; 163:217-236. [PubMed: 9700513]

2. Chen L, Flies DB. Molecular mechanisms of T cell co-stimulation and co-inhibition. Nat. Rev. Immunol. 2013; 13:227-242. [PubMed: 23470321]

3. Webber A, Hirose R, Vincenti F. Novel strategies in immunosuppression: issues in perspective. Transplantation. 2011; 91:1057-1064. [PubMed: 21412186]

4. Wakisaka S, Suzuki N, Nagafuchi H, Takeba Y, Kaneko A, Asai T, Sakane T. Characterization of tissue outgrowth developed in vitro in patients with rheumatoid arthritis: involvement of $\mathrm{T}$ cells in the development of tissue outgrowth. Int. Arch. Allergy Immunol. 2000; 121:68-79. [PubMed: 10686511]

5. Balanescu A, Radu E, Nat R, Regalia T, Bojinca V, Predescu V, Predeteanu D. Co-stimulatory and adhesion molecules of dendritic cells in rheumatoid arthritis. J. Cell. Mol. Med. 2002; 6:415-425. [PubMed: 12417058]

6. Kurko J, Besenyei T, Laki J, Glant TT, Mikecz K, Szekanecz Z. Genetics of rheumatoid arthritis - a comprehensive review. Clin. Rev. Allergy Immunol. 2013; 45:170-179. [PubMed: 23288628]

7. Raychaudhuri S, Thomson BP, Remmers EF, Eyre S, Hinks A, Guiducci C, Catanese JJ, Xie G, Stahl EA, Chen R, Alfredsson L, Amos CI, Ardlie KG, Barton A, Bowes J, Burtt NP, Chang M, Coblyn J, Costenbader KH, Criswell LA, Crusius JB, Cui J, De Jager PL, Ding B, Emery P, Flynn E, Harrison P, Hocking LJ, Huizinga TW, Kastner DL, Ke X, Kurreeman FA, Lee AT, Liu X, Li Y, Martin P, Morgan AW, Padyukov L, Reid DM, Seielstad M, Seldin MF, Shadick NA, Steer S, Tak PP, Thomson W, van der Helm-van Mil AH, van der Horst-Bruinsma IE, Weinblatt ME, Wilson AG, Wolbink GJ, Wordsworth P, Altshuler D, Karlson EW, Toes RE, de Vries N, Begovich AB, Siminovitch KA, Worthington J, Klareskog L, Gregersen PK, Daly MJ, Plenge RM. Genetic variants at CD28, PRDM1 and CD2/CD58 are associated with rheumatoid arthritis risk. Nat. Genet. 2009; 41:1313-1318. [PubMed: 19898481]

8. Mrowietz U. Treatment targeted to cell surface epitopes. Clin. Exp. Dermatol. 2002; 27:591-596. [PubMed: 12464155]

9. Chamian F, Lowes MA, Lin SL, Lee E, Kikuchi T, Gilleaudeau P, Sullivan-Whalen M, Cardinale I, Khatcherian A, Novitskaya I, Wittkowski KM, Krueger JG. Alefacept reduces infiltrating T cells, activated dendritic cells, and inflammatory genes in psoriasis vulgaris. Proc. Natl. Acad. Sci. U. S. A. 2005; 102:2075-2080. [PubMed: 15671179]

10. Wang JH, Smolyar A, Tan K, Liu JH, Kim M, Sun ZY, Wagner G, Reinherz EL. Structure of a heterophilic adhesion complex between the human CD2 and CD58 (LFA-3) counterreceptors. Cell. 1999; 97:791-803. [PubMed: 10380930]

11. Gokhale A, Weldeghiorghis TK, Taneja V, Satyanarayanajois SD. Conformationally constrained peptides from CD2 to modulate protein-protein interactions between CD2 and CD58. J. Med. Chem. 2011; 54:5307-5319. [PubMed: 21755948]

12. Gokhale A, Kanthala S, Latendresse J, Taneja V, Satyanarayanajois S. Immunosuppression by costimulatory molecules: inhibition of CD2-CD48/CD58 interaction by peptides from CD2 to 
suppress progression of collagen-induced arthritis in mice. Chem. Biol. Drug Des. 2013; 82:106118. [PubMed: 23530775]

13. Brand DD, Latham KA, Rosloniec EF. Collagen-induced arthritis. Nat. Protoc. 2007; 2:1269-1275. [PubMed: 17546023]

14. Vlieghe P, Lisowski V, Martinez J, Khrestchatisky M. Synthetic therapeutic peptides: science and market. Drug Discovery Today. 2010; 15:40-56. [PubMed: 19879957]

15. Poth AG, Chan LY, Craik DJ. Cyclotides as grafting frameworks for protein engineering and drug design applications. Biopolymers Pept. Sci. 2013; 100:480-491.

16. Craik DJ, Daly NL, Bond T, Waine C. Plant cyclotides: A unique family of cyclic and knotted proteins that defines the cyclic cystine knot structural motif. J. Mol. Biol. 1999; 294:1327-1336. [PubMed: 10600388]

17. Luckett S, Garcia RS, Barker JJ, Konarev AV, Shewry PR, Clarke AR, Brady RL. High-resolution structure of a potent, cyclic proteinase inhibitor from sunflower seeds. J. Mol. Biol. 1999; 290:525-533. [PubMed: 10390350]

18. Craik DJ, Swedberg JE, Mylne JS, Cemazar M. Cyclotides as a basis for drug design. Expert Opin. Drug Discovery. 2012; 7:179-194.

19. Daly NL, Chen YK, Rosengren KJ, Marx UC, Phillips ML, Waring AJ, Wang W, Lehrer RI, Craik DJ. Retrocyclin-2: structural analysis of a potent anti-HIV theta-defensin. Biochemistry. 2007; 46:9920-9928. [PubMed: 17685559]

20. Kim M, Sun ZY, Byron O, Campbell G, Wagner G, Wang J, Reinherz EL. Molecular dissection of the CD2-CD58 counter-receptor interface identifies CD2 Tyr86 and CD58 Lys34 residues as the functional "hot spot. J. Mol. Biol. 2001; 312:711-720. [PubMed: 11575926]

21. Korsinczky ML, Schirra HJ, Rosengren KJ, West J, Condie BA, Otvos L, Anderson MA, Craik DJ. Solution structures by 1H NMR of the novel cyclic trypsin inhibitor SFTI-1 from sunflower seeds and an acyclic permutant. J. Mol. Biol. 2001; 311:579-591. [PubMed: 11493011]

22. Wang CK, King GJ, Northfield SE, Ojeda PG, Craik DJ. Racemic and quasi-racemic X-ray structures of cyclic disulfide-rich peptide drug scaffolds. Angew. Chem., Int. Ed. 2014; 53:1123611241.

23. Conibear AC, Rosengren KJ, Harvey PJ, Craik DJ. Structural characterization of the cyclic cystine ladder motif of theta-defensins. Biochemistry. 2012; 51:9718-9726. [PubMed: 23148585]

24. Krieger E, Koraimann G, Vriend G. Increasing the precision of comparative models with YASARA NOVA-a self-parameterizing force field. Proteins: Struct., Funct., Genet. 2002; 47:393-402. [PubMed: 11948792]

25. Cheneval O, Schroeder CI, Durek T, Walsh P, Huang YH, Liras S, Price DA, Craik DJ. Fmocbased synthesis of disulfide-rich cyclic peptides. J. Org. Chem. 2014; 79:5538-5544. [PubMed: 24918986]

26. Takai Y, Reed ML, Burakoff SJ, Herrmann SH. Direct evidence for a receptor-ligand interaction between the T-cell surface antigen CD2 and lymphocyte-function-associated antigen 3. Proc. Natl. Acad. Sci. U. S. A. 1987; 84:6864-6868. [PubMed: 3309949]

27. Nel AE, Ledbetter JA, Williams K, Ho P, Akerley B, Franklin K, Katz R. Activation of MAP-2 kinase activity by the CD2 receptor in Jurkat T cells can be reversed by CD45 phosphatase. Immunology. 1991; 73:129-133. [PubMed: 1676984]

28. Abraham RT, Weiss A. Jurkat T cells and development of the T-cell receptor signalling paradigm. Nat. Rev. Immunol. 2004; 4:301-308. [PubMed: 15057788]

29. Hunig T. The cell surface molecule recognized by the erythrocyte receptor of T lymphocytes. Identification and partial characterization using a monoclonal antibody. J. Exp. Med. 1985; 162:890-901. [PubMed: 2411842]

30. Albert-Wolf M, Meuer SC, Wallich R. Dual function of recombinant human CD58: inhibition of T cell adhesion and activation via the CD2 pathway. Int. Immunol. 1991; 3:1335-1347. [PubMed: 1723296]

31. Dengler TJ, Hoffmann JC, Knolle P, Albert-Wolf M, Roux M, Wallich R, Meuer SC. Structural and functional epitopes of the human adhesion receptor CD58 (LFA-3). Eur. J. Immunol. 1992; 22:2809-2817. [PubMed: 1385151] 
32. Komolov KE, Koch KW. Application of surface plasmon resonance spectroscopy to study Gprotein coupled receptor signalling. Methods Mol. Biol. 2010; 627:249-260. [PubMed: 20217627]

33. van der Merwe PA, Davis SJ. Molecular interactions mediating T cell antigen recognition. Annu. Rev. Immunol. 2003; 21:659-684. [PubMed: 12615890]

34. Zhu DM, Dustin ML, Cairo CW, Golan DE. Analysis of two-dimensional dissociation constant of laterally mobile cell adhesion molecules. Biophys. J. 2007; 92:1022-1034. [PubMed: 17085486]

35. Taneja V, Krco CJ, Behrens MD, Luthra HS, Griffiths MM, David CS. B cells are important as antigen presenting cells for induction of MHC-restricted arthritis in transgenic mice. Mol. Immunol. 2007; 44:2988-2996. [PubMed: 17303243]

36. Taneja V, Taneja N, Behrens M, Griffiths MM, Luthra HS, David CS. Requirement for CD28 may not be absolute for collagen-induced arthritis: study with HLA-DQ8 transgenic mice. J. Immunol. 2005; 174:1118-1125. [PubMed: 15634938]

37. Knutson KL, dela Rosa C, Disis ML. Laboratory analysis of T-cell immunity. Front. Biosci., Landmark Ed. 2006; 11:1932-1944.

38. Hess S, Ovadia O, Shalev DE, Senderovich H, Qadri B, Yehezkel T, Salitra Y, Sheynis T, Jelinek R, Gilon C, Hoffman A. Effect of structural and conformation modifications, including backbone cyclization, of hydrophilic hexapeptides on their intestinal permeability and enzymatic stability. J. Med. Chem. 2007; 50:6201-6211. [PubMed: 17983214]

39. Hunter HN, Jing W, Schibli DJ, Trinh T, Park IY, Kim SC, Vogel HJ. The interactions of antimicrobial peptides derived from lysozyme with model membrane systems. Biochim. Biophys. Acta, Biomembr. 2005; 1668:175-189.

40. Tugyi R, Uray K, Ivan D, Fellinger E, Perkins A, Hudecz F. Partial D-amino acid substitution: Improved enzymatic stability and preserved $\mathrm{Ab}$ recognition of a MUC2 epitope peptide. Proc. Natl. Acad. Sci. U. S. A. 2005; 102:413-418. [PubMed: 15630090]

41. Pappa EV, Zompra AA, Spyranti Z, Diamantopoulou Z, Pairas G, Lamari FN, Katsoris P, Spyroulias GA, Cordopatis P. Enzymatic stability, solution structure, and antiproliferative effect on prostate cancer cells of leuprolide and new gonadotropin-releasing hormone peptide analogs. Biopolymers. 2011; 96:260-272. [PubMed: 20632397]

42. Brauer AB, Domingo GJ, Cooke RM, Matthews SJ, Leatherbarrow RJ. A conserved cis peptide bond is necessary for the activity of Bowman-Birk inhibitor protein. Biochemistry. 2002; 41:10608-10615. [PubMed: 12186545]

43. Tischler M, Nasu D, Empting M, Schmelz S, Heinz DW, Rottmann P, Kolmar H, Buntkowsky G, Tietze D, Avrutina O. Braces for the peptide backbone: insights into structure-activity relationships of protease inhibitor mimics with locked amide conformations. Angew. Chem., Int. Ed. 2012; 51:3708-3712.

44. Morris GM, Huey R, Lindstrom W, Sanner MF, Belew RK, Goodsell DS, Olson AJ. AutoDock4 and AutoDockTools4: Automated docking with selective receptor flexibility. J. Comput. Chem. 2009; 30:2785-2791. [PubMed: 19399780]

45. Satyanarayanajois SD, Ronald S, Liu J. Heterotypic cell adhesion assay for the study of cell adhesion inhibition. Methods Mol. Biol. 2011; 716:225-243. [PubMed: 21318910]

46. Albert-Wolf M, Meuer SC, Wallich R. Dual function of recombinant human CD58: inhibition of T cell adhesion and activation via the CD2 pathway. Int. Immunol. 1991; 3:1335-1347. [PubMed: 1723296]

47. Taneja V, David CS. Role of HLA class II genes in susceptibility/resistance to inflammatory arthritis: studies with humanized mice. Immunol. Rev. 2010; 233:62-78. [PubMed: 20192993] 

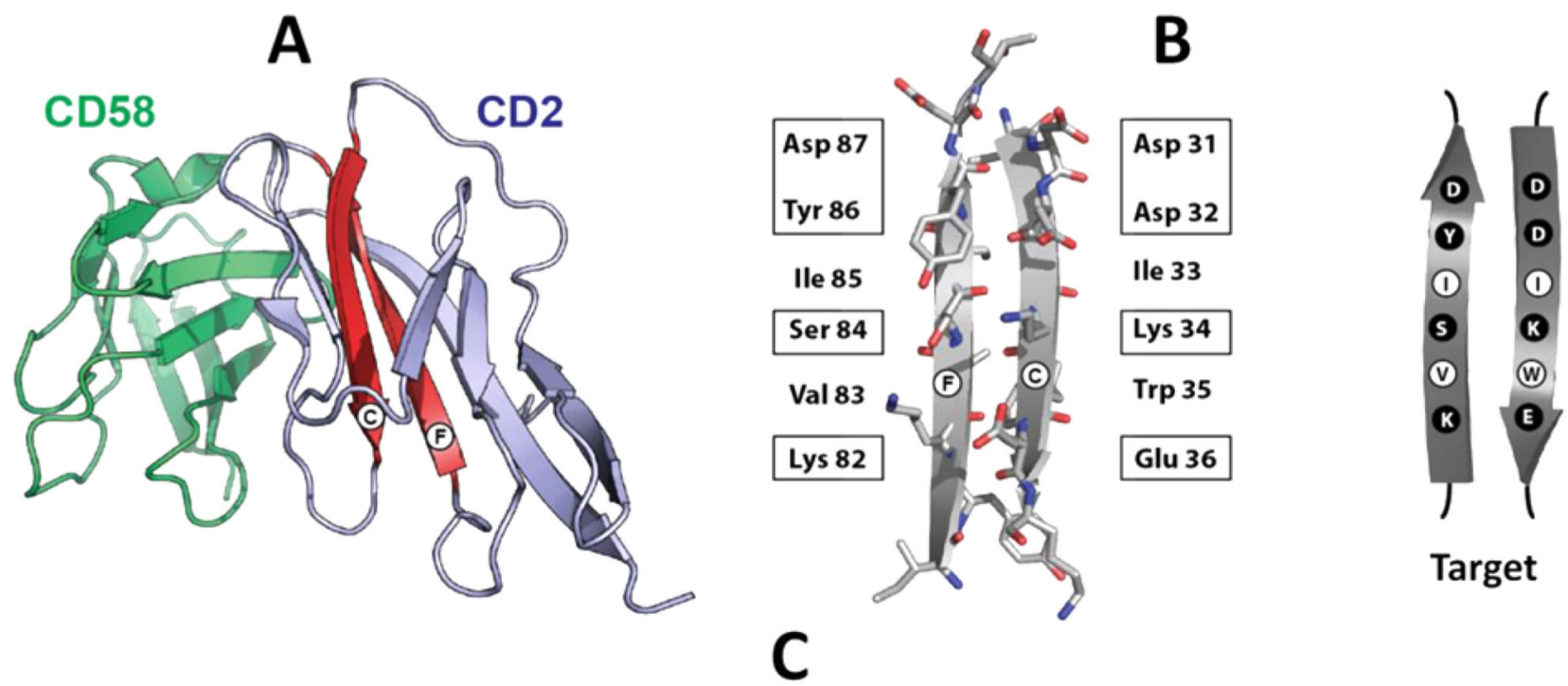

Target
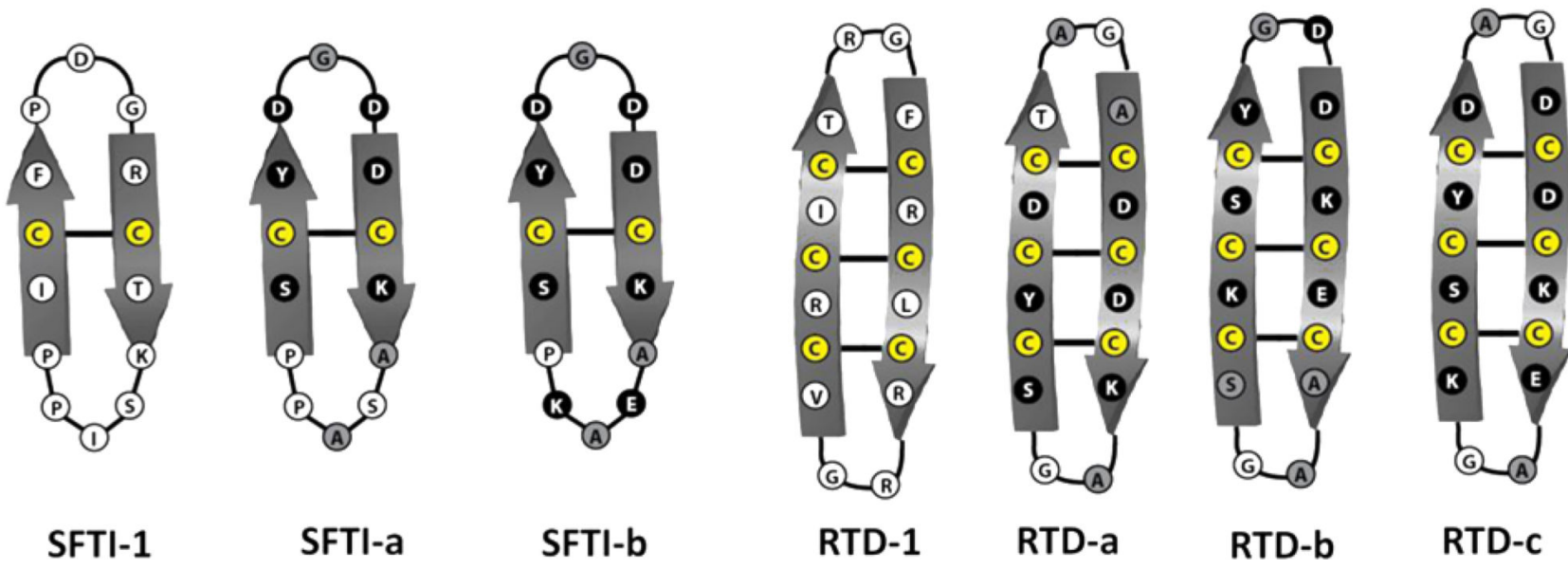

\section{SFTI-1}
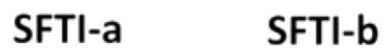

RTD-1

RTD-a

RTD-b

Figure 1.

Grafting of CD2 epitopes onto circular protein frameworks. (A) Complex of the adhesion domains of CD2 (blue) and CD58 (green) with C and F strands highlighted in red. (B) Structures of the isolated $\mathrm{C}$ and $\mathrm{F}$ strands. Boxed residues of $\mathrm{CD} 2$ form the core interface engaging CD58. (C) Grafting of the F and C strand amino acids of CD2 onto the SFTI or a RTD frameworks. 

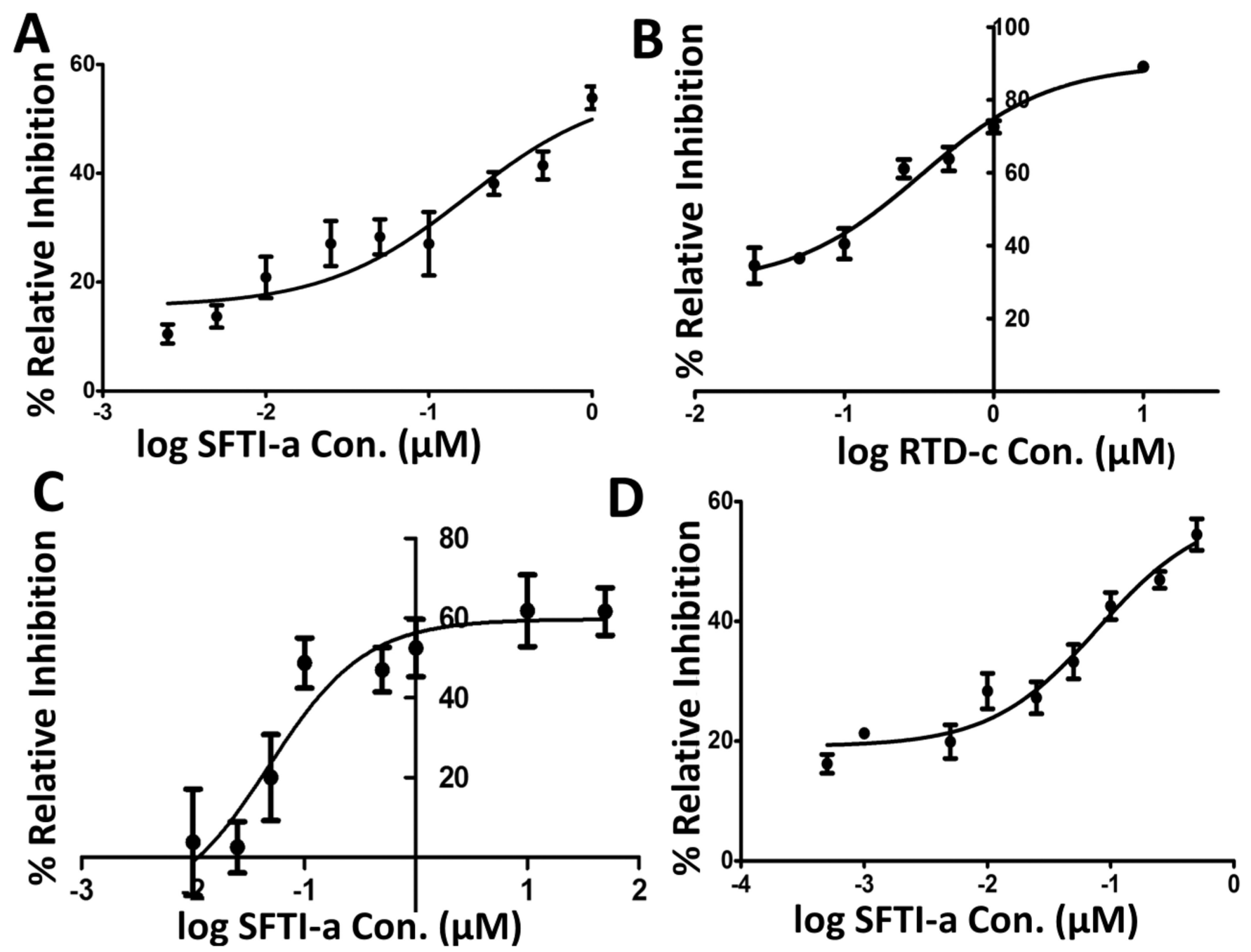

Figure 2.

Inhibition of cell adhesion by SFTI-a and RTD-c. (A) Dose response curve for cell adhesion inhibition of Jurkat cells that express CD2 and OVCAR- 3 cells that express CD58 by SFTI-a peptide. For comparison, inhibition by antibody to CD58 was considered $100 \%$ inhibition. (B) Inhibition of cell adhesion by RTD-c in the lymphocyte-epithelial assay (Jurkat and OVCAR-3 cells). (C) Jurkat cells and sheep red blood cells by SFTI-a. (D) Dose response curve for cell adhesion inhibition by SFTI-a (Jurkat and HFLS-RA). 


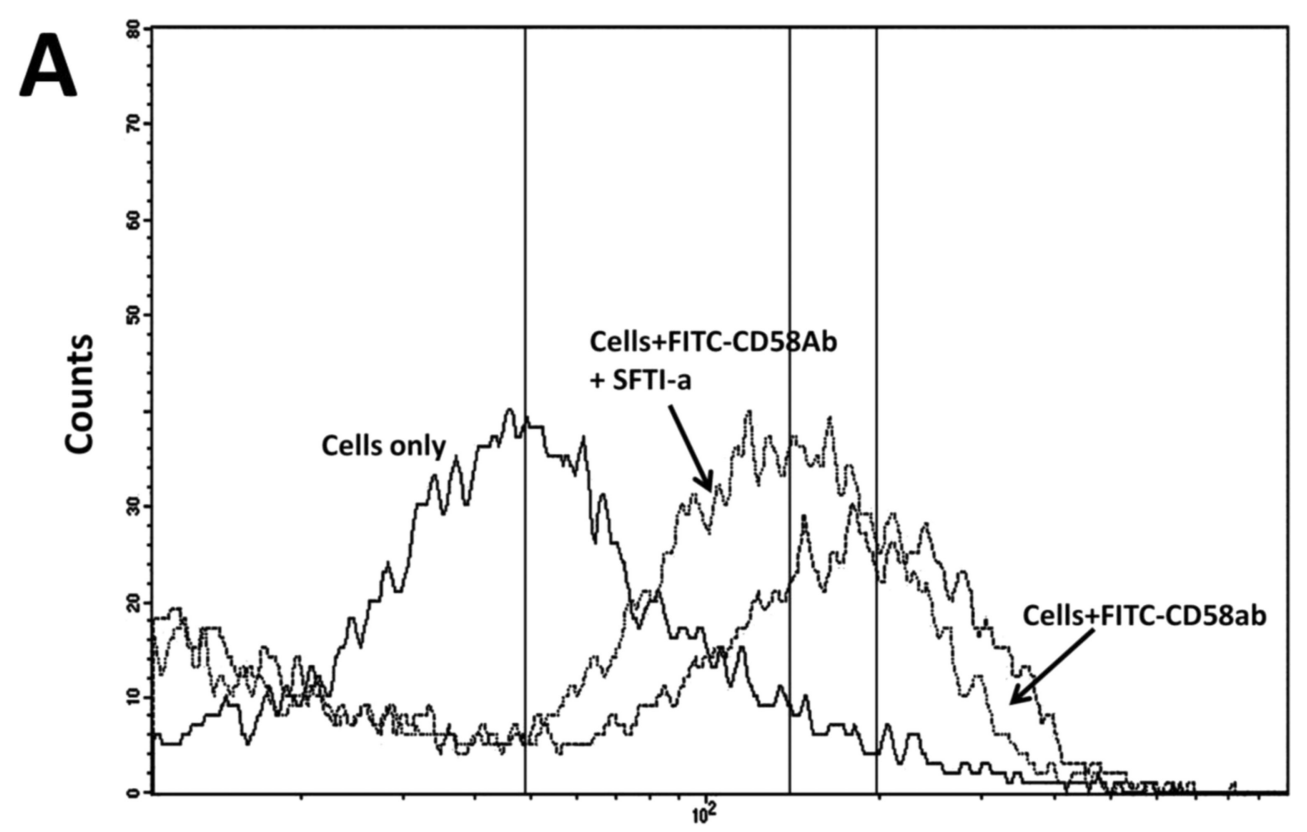

B

FL1-H

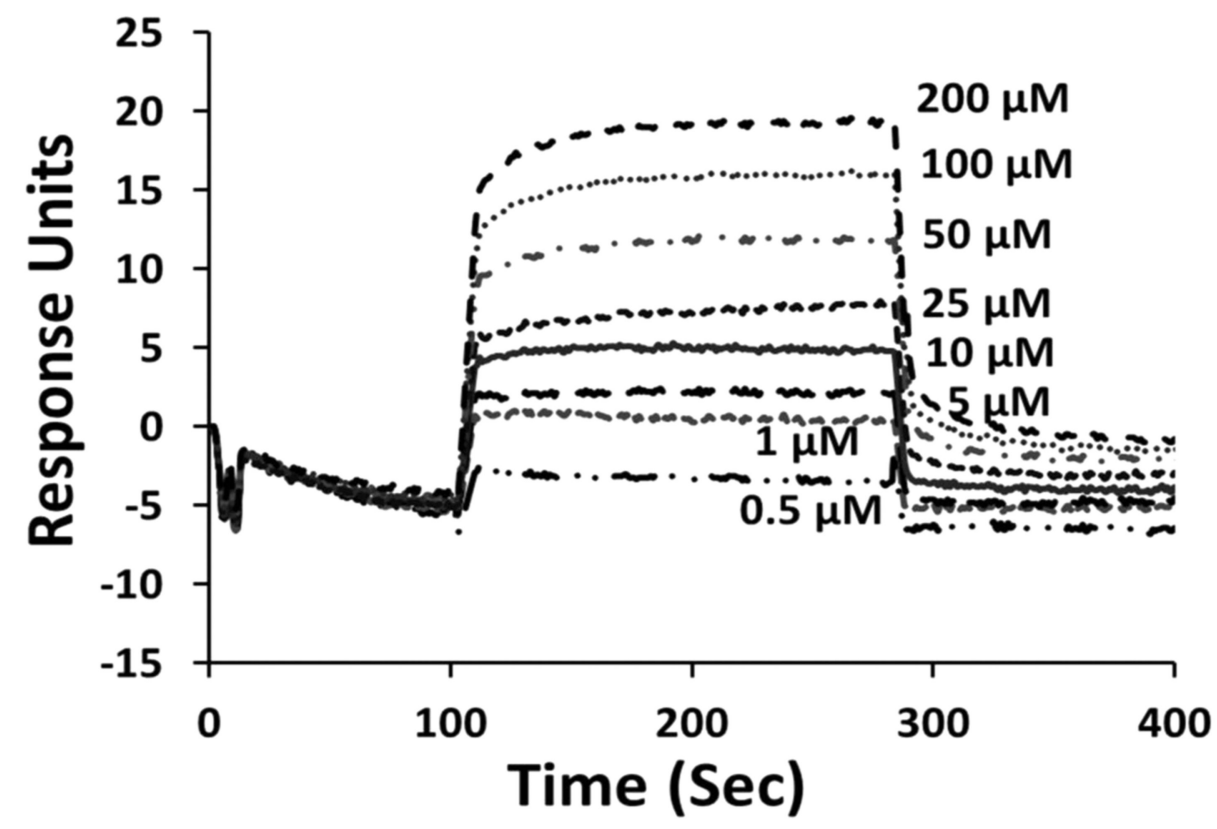

Figure 3.

(A) Inhibition of antibody (FITC-CD58Ab) binding to cells that express CD58 by SFTI-a studied by flow-cytometry. Note that unbound cells are only on the left side. Upon binding to FITC-CD58 Ab, the cells that bind to Ab are shifted to the right. In the presence of peptide SFTI-a, antibody binding was inhibited as indicated by a shift in the cell population to the left. (B) Binding of SFTI-1a to CD58 protein studied by SPR. CD58 protein was immobilized on a CM-5 chip, and SFTI-a was used as an analyte. Sensograms indicate SFTI-a binding to CD58 at different concentrations. Association and dissociation kinetics 
revealed a $K_{\mathrm{D}}$ of $14.6 \mu \mathrm{M}$ for the SFTI-a:CD58 interaction. Sensograms were references with respect to a surface with only CD58 protein immobilized and difference in the response units was plotted for presentation. Baseline was subtracted to plot the sensograms. 


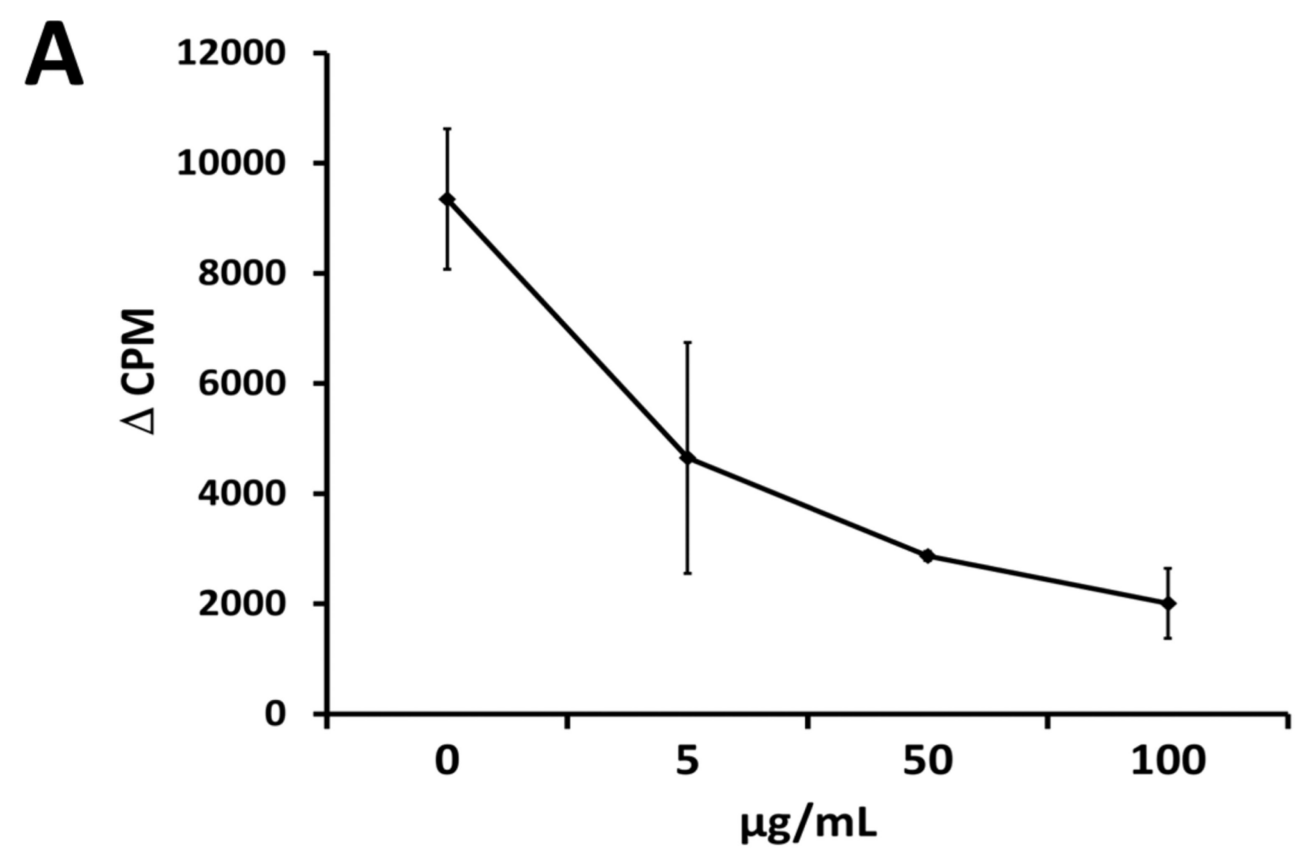

B

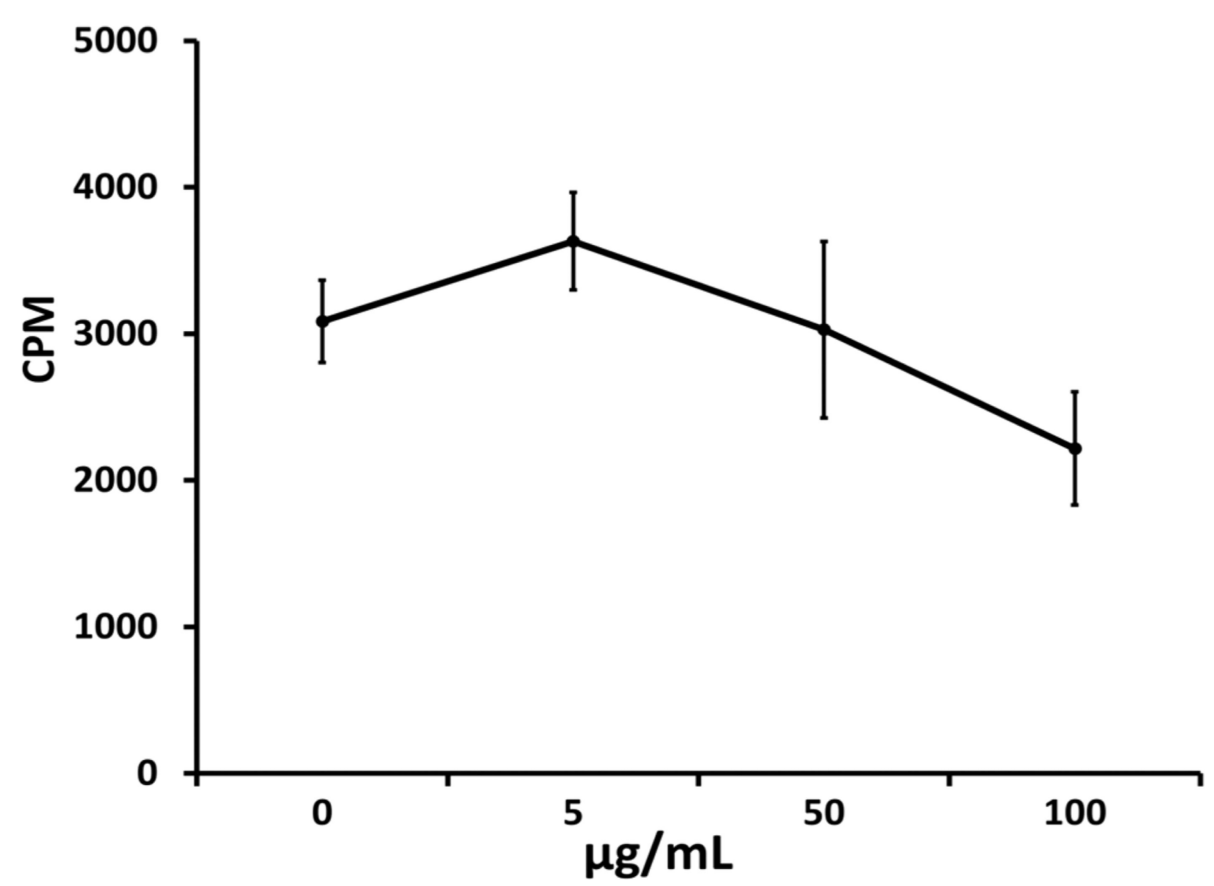

Figure 4.

(A) T cell suppression assay. Lymph node cells (LNCs) harvested from type II collagen (CII)-immunized DQ8 mice were cultured in vitro in the presence or absence of CII and various concentrations of SFTI-a ( $n=3 /$ group) and T cell proliferation was measured. SFT1a suppressed antigen-specific T cell response. (B) Immunogenicity of SFT1-a was tested in DQ8 mice. DQ8 mice were immunized with SFTI-a. Ten days postimmunization, LNCs were harvested and cultured without or with various concentrations of SFTI-a, and T cell response was measured as per standard methods. No immune response was generated to 
SFT1-a at $50 \mu \mathrm{g} / \mathrm{mL}$ as compared to media control $(n=2)$, suggesting SFT1-a is not immunogenic. 

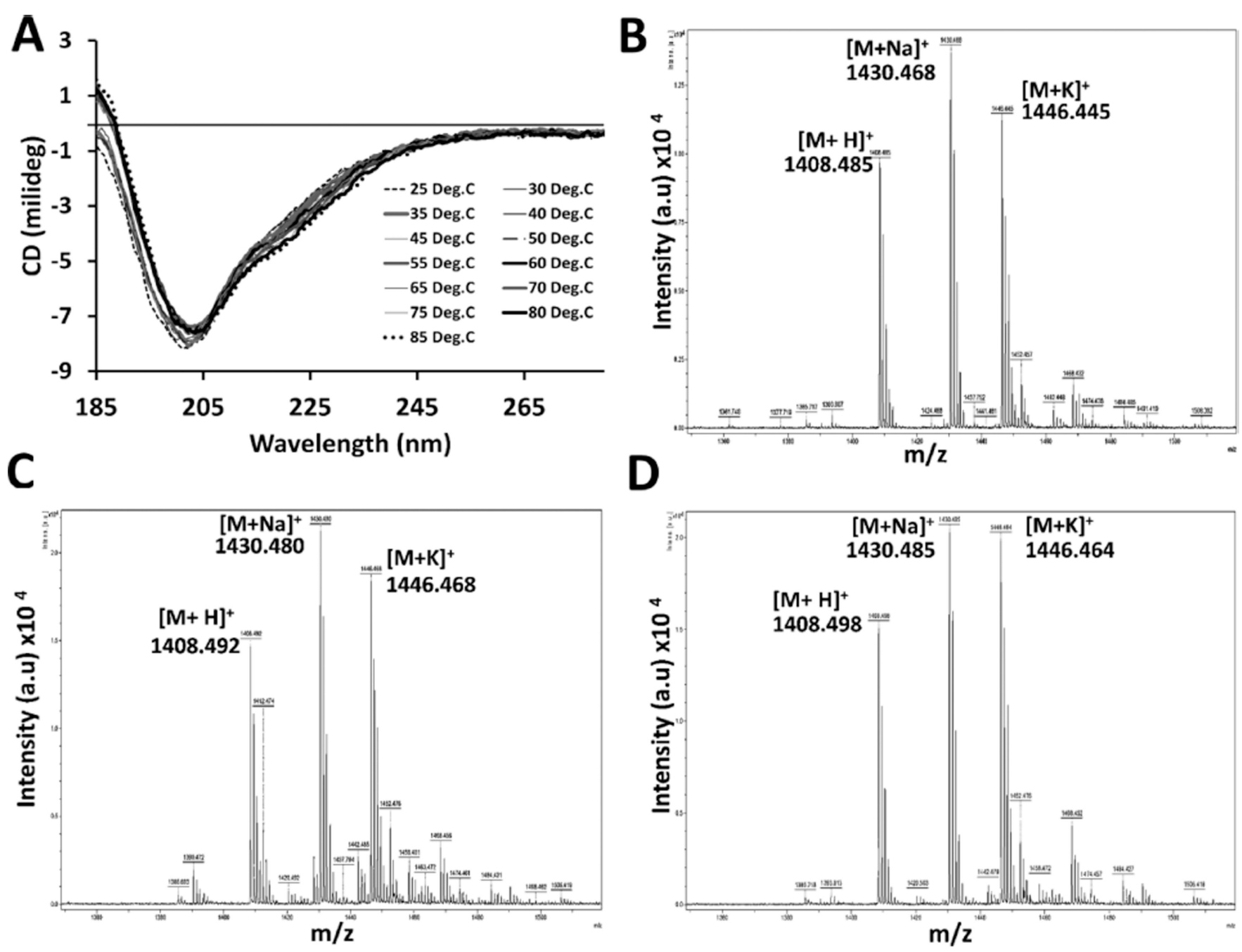

Figure 5.

(A) CD spectra of SFTI-a in water at different temperatures from 25 to $85^{\circ} \mathrm{C}$. Note that the spectrum of the peptide has a negative band around $202 \mathrm{~nm}$, and the wavelength of negative maximum and the intensity of the band were not significantly changed upon an increase in temperature, suggesting a stable secondary structure of the peptide in solution. (B) Mass spectrum of the freshly prepared sample and (C) mass spectrum of the peptide that was heated to $25^{\circ} \mathrm{C}$ (D) after a temperature cycle to $85^{\circ} \mathrm{C}$. There was no change in the $\mathrm{CD}$ and MS spectra of the peptide, suggesting the peptide was stable to temperature induced denaturation. 


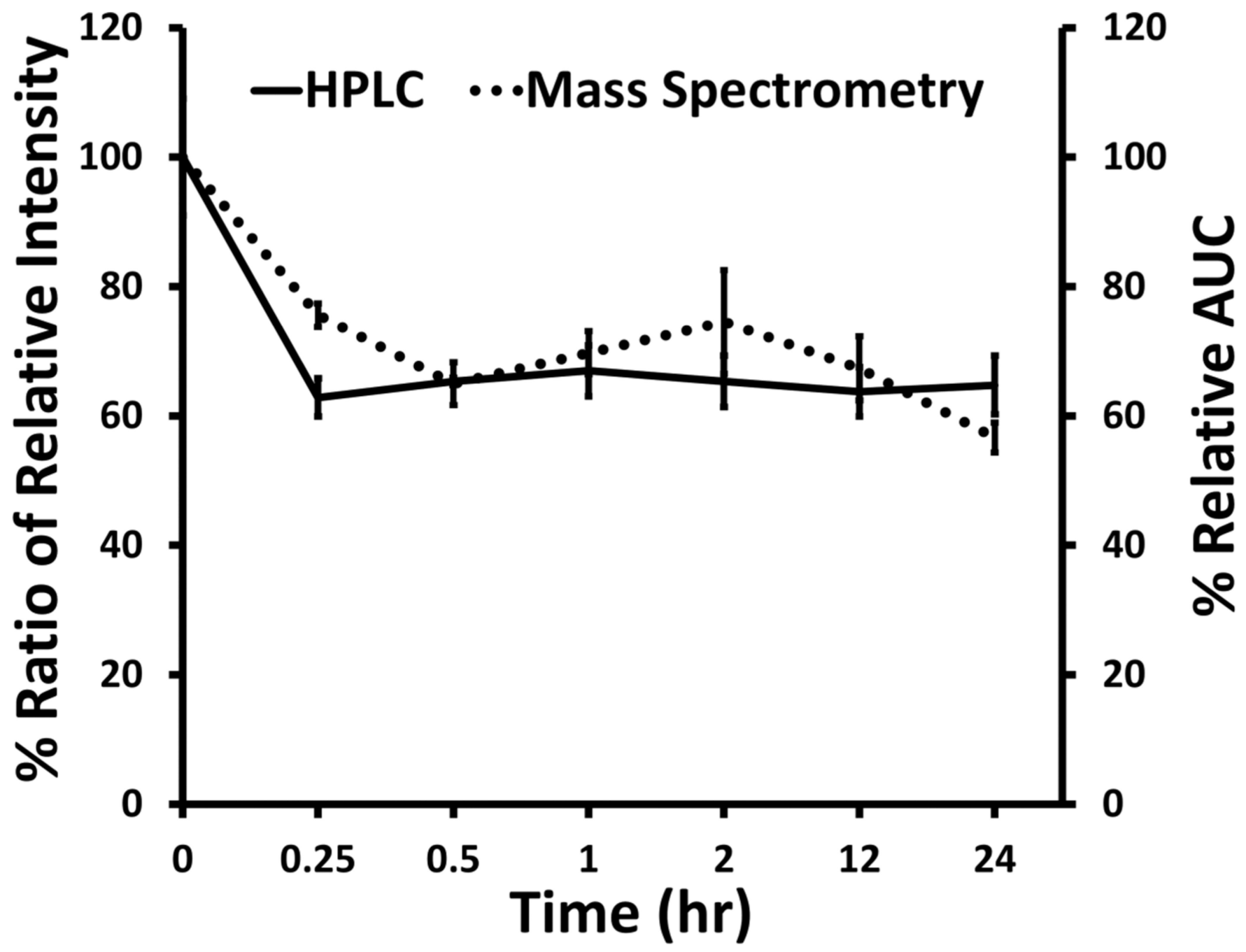

Figure 6.

Serum stability (in vitro) of SFTI-a studied by analytical HPLC and mass spectrometry (MALDI-TOF). The $y$ axis represents the amount of intact peptide remaining. A total of 200 $\mu \mathrm{L}$ of stock solutions of SFTI-a was treated with $1 \mathrm{~mL}$ of human serum. Samples were analyzed by HPLC as well as TOF-MS. In the case of HPLC, relative area under the curve (AUC) was plotted. Mass spectra were acquired after calibration of the instrument with a peptide standard. Zero time point chromatogram/mass spectrum was considered as $100 \%$. Relative intensity is plotted with respect to time, and data are from triplicate experiments. 


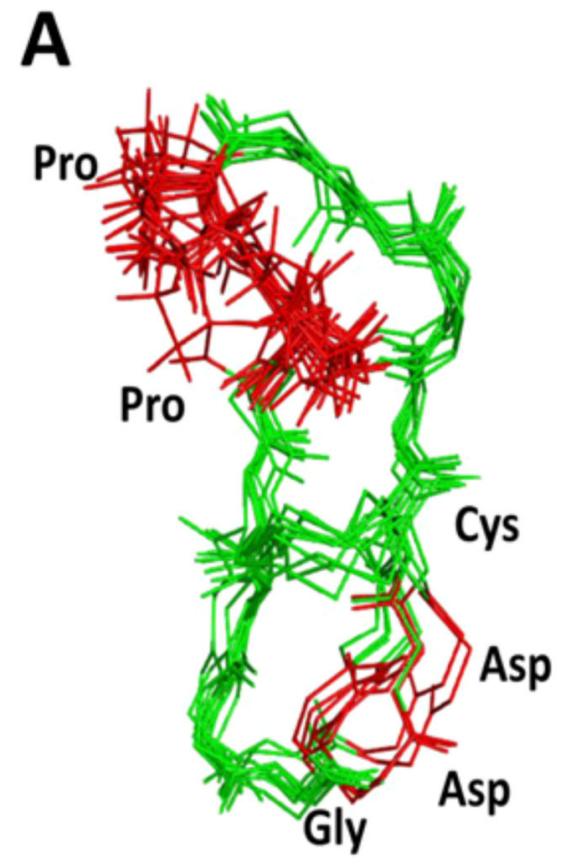

B
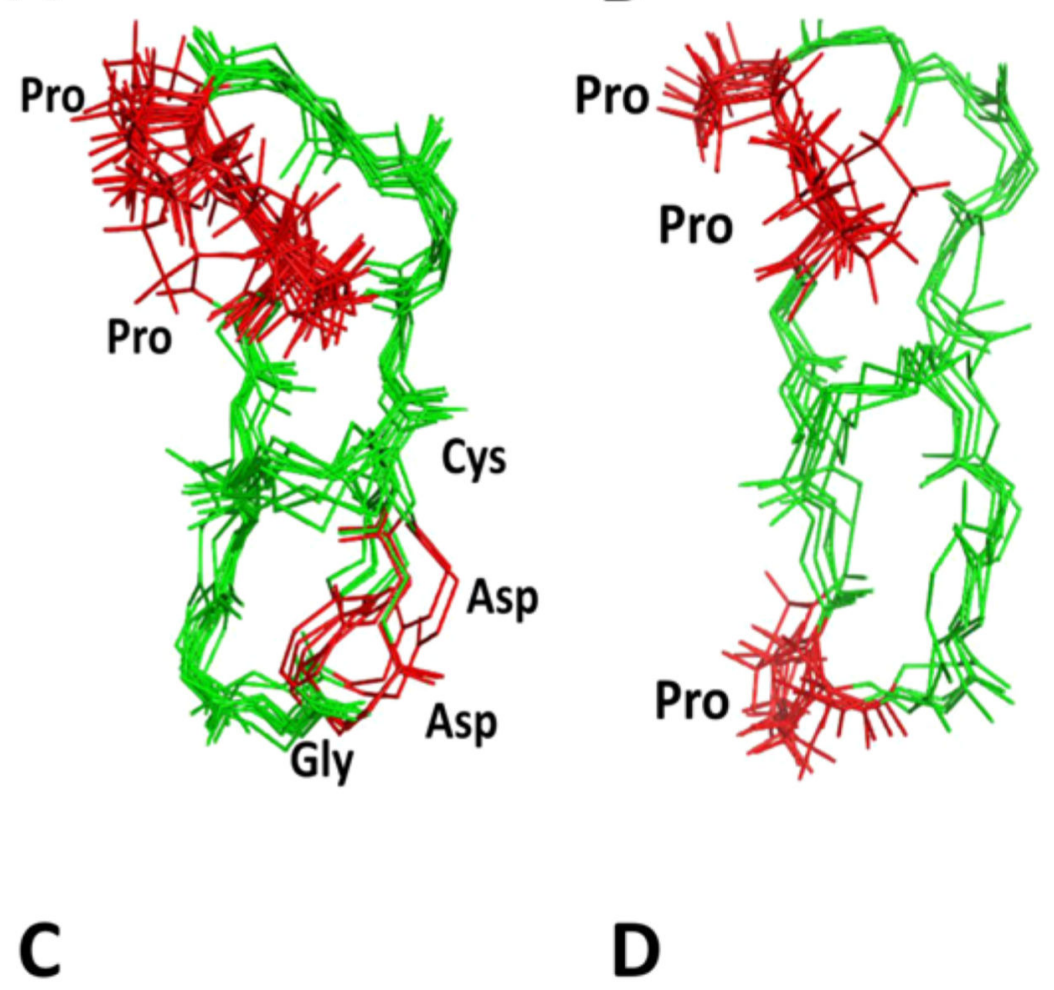

D
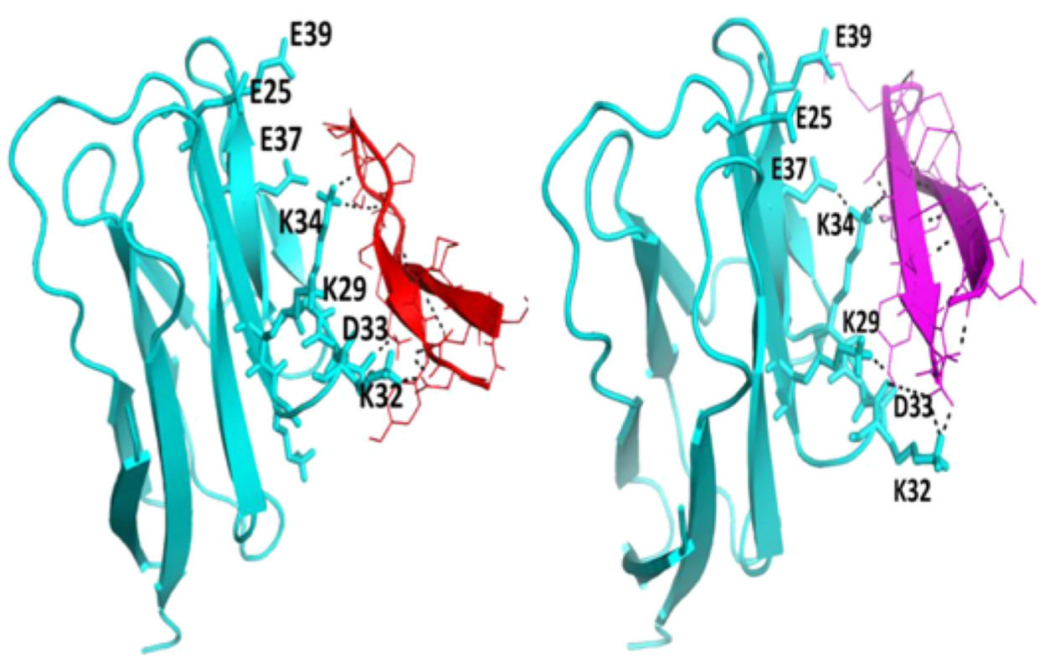

Figure 7.

Overlayed structures of SFTI-a and SFTI-1 (wt) from the trajectory of MD simulations for 400 ps showing the backbone flexibility of peptides. (A) Backbone of SFTI-a with 10 overlapped structures. Pro-Pro and Asp that showed flexibility are shown in red color. (B) Backbone of SFTI-1 with eight overlapped structures. Pro-Pro and another proline in the structure are shown in red, indicating the flexibility in the peptide. Low energy docked structures of (C) SFTI-a and (D) RTD-c bound to CD58 protein adhesion domain. Notice 
that the peptide interacts with the adhesion domain of amino acids from CD58 that are important in binding to $\mathrm{CD} 2$. 
Table 1

Sequences of Novel Grafted Cyclic Peptides and Peptide $6^{a}$

\begin{tabular}{|c|c|c|c|c|}
\hline \multirow[b]{2}{*}{ code } & \multirow[b]{2}{*}{ sequence } & \multicolumn{3}{|c|}{ cell adhesion inhibition $\mathrm{IC}_{50}(\mu \mathrm{M})$} \\
\hline & & molecular weight $b$ & T cell OVCAR-3 & T cell HFLS-RA \\
\hline peptide 6 & cyclo $(1,10)$ SIYDpPDDIK & 1144.2 & $0.0069 \pm 0.0004$ & ND \\
\hline SFTI-1 & CTKSIPPICFPDGR & 1512.8 & $>50$ & $>50$ \\
\hline SFTI-a & CKASAPPSCYDGDD & 1407.5 & $0.043 \pm 0.025$ & $0.051 \pm 0.025$ \\
\hline SFTI-b & CKAEAKPSCYDGDD & 1480.6 & $>50$ & $>50$ \\
\hline RTD-a & $\underline{\text { GACDCDC }} \underline{\mathrm{KAGSCYCDCTA}}$ & 1763.5 & $>50$ & $>50$ \\
\hline RTD-b & $\underline{\text { DDCKCECAAASCKCSCYY }}$ & 1820.6 & $>50$ & $>50$ \\
\hline RTD-c & $\underline{\text { GDCDCKCEAGKCSCYCDA }}$ & 1848.5 & $0.027 \pm 0.015$ & ND \\
\hline control & KGKTDAISVKAI-NH2 & 1228.7 & $>100$ & $>100$ \\
\hline compound $35^{c}$ & Cyclo(PpR-(R)Anapa-FF- (R)Anapa-R & 1195.3 & ND & ND \\
\hline \multicolumn{5}{|c|}{$\begin{array}{l}\text { a Cyclic peptides (SFTI-a,b, RTD-a-c). Grafted residues from the CD2 peptide } 6 \text { are shown in bold. Capital letters refer to L-amino acids; lower } \\
\text { case letters refer to D-amino acids. ND, not determined. }\end{array}$} \\
\hline
\end{tabular}

